\title{
PENYELESAIAN PERSELISIHAN ANTARA NEGARA DENGAN WARGA NEGARA ASING MENGENAI PENANAMAN MODAL BERBASIS PANCASILA
}

Oleh:

\author{
Agus Saiful Abib \\ Fakultas Hukum Universitas Semarang (USM) \\ agus_saifulabib@yahoo.com
}

\begin{abstract}
ASBTRAK
Indonesia adalah negara hukum (rechtsstaat), oleh karena itu hukum nasional harus berdaulat dan menjadi panglima dalam menyelesaiaikan seluruh permasalahan bangsa. Akan tetapi penyelesaian perselisihan antara negara dengan warga negara asing mengenai penanaman modal dalam hegemoni hukum arbitrase internasinal, dimana pemerintah menyerahkan mekanismenya kepada International Centre for Settlement of Investment Disputte (ICSID). Fokus permasalahan makalah ini adalah Bagaimanakah keuntungan dan kerugian pemerintah Indonesia dalam penyelesian perselisihan antara negara dengan warganegara asing mengenai penanaman modal melalui ICSID? Bagaimanakah konsep penyelesian perselisihan antara negara dengan warga negara asing mengenai penanaman modal dalam sistem hukum nasional berbasis Pancasila?

Metode yang digunakan dalam makalah ini adalah Analisa kualitatif dengan menggunakan paradigma postpositivisme (Guba \& Lincoln) yang disinergikan dengan pendekatan sosiolegal. Penulisan makalah ini mengungkapkan Hukum nasional merupakan hukum yang dibangun oleh bangsa Indonesia sendiri berdasarkan nilai ketuhanan, nilai kemanusiaan dan nilai kemasyarakatan yang merupakan nilai agung Pancasila sebagai pandangan hidup bangsa Indonesia guna mewujudkan tujuan negara. Indonesia mengalami kerugian sangat besar ketika penyelesaian perselisihan antara negara dengan warganegara asing mengenai penanaman modal diserahkan kepada ICSID, Oleh karena itu, perselisihan penanaman modal sebaiknya diselesaikan oleh badan arbitrase ASEAN.
\end{abstract}

Kata Kunci : Perselisihan, Penanaman Modal, Pancasila.

\section{Abstract}

Indonesia is a state of law (rechtsstaat), therefore the national law must be sovereign and be the commander in solving all the problems of the nation. However, the settlement of disputes between the state and foreign citizens concerning investment in the hegemony of the international arbitration law, in which the government submits its mechanism to the International Center for Settlements of Investment Disputes (ICSID). The focus of this paper issue is how are the gains and losses of the Indonesian government in settling disputes between the state and foreign citizens on investment through ICSID? What is the concept of dispute settlement between state and foreign citizen regarding investment in national legal system based on Pancasila? 
The method used in this paper is qualitative analysis using postpositivism paradigm (Guba \& Lincoln) synergized with sociolegal approach. The writing of this paper reveals the national law is a law that was built by the Indonesian people themselves based on the value of divinity, humanitarian values and community values which is the great value of Pancasila as a view of life of the Indonesian nation in order to realize the purpose of the state. Indonesia suffers enormous losses when the settlement of disputes between the state and foreign citizens concerning investment is left to ICSID. Therefore, investment disputes should be resolved by the ASEAN arbitration body.

Keywords: Disputes, Investment, Pancasila.

\section{A. LATAR BELAKANG}

Pancasila merupakan landasan ideologis, yuridis, filosofis, cita hukum dan norma fundamental bangsa Indonesia dalam membentuk peraturan perundangundangan guna mewujudkan keadilan bagi seluruh rakyat Indonesia. Pancasila harus dijadikan sebagai paradigma (payung berfikir, cara pandang, arah kebijakan) dalam pembentukan, pembaruan, serta pembangunan hukum nasional. Pembaruan dan pembangunan hukum nasional yang berlandaskan Pancasila adalah upaya mempertahankan sekaligus menunjukkan jati diri hukum nasional ditengah arus sistem hukum global. Demikian pula dalam pembentukan peraturan perundang-undangan wajib disinari oleh Pancasila sebagai filter guna melindungi masyarakat dari peraturan yang tidak sesuai dengan nilai-nilai luhur bangsa.

Saat ini hukum Indonesia dipandang sebagai aturan yang tidak baku dan tidak kaku, sehingga dimungkinkan hukum nasional masih dapat berubah sepanjang memenuhi syarat untuk mengikuti perkembangan jaman guna mencapai tujuan negara. Menurut Gustav Radbruch ${ }^{1}$ hukum itu harus memenuhi tiga nilai yaitu keadilan, kegunaan, dan kepastian hukum. Oleh karena itu perubahan hukum idealnya harus membawa implikasi positif dengan adanya nilai-nilai keadilan, kegunaan dan kepatian hukum guna memperkokoh pembangunan dan pembaharuan hukum nasional. Pembaharuan hukum dapat dilakukan pemerintah terhadap hukum nasional yang tidak berdasarkan nilai-nilai keadilan, kepastian, dan kemanfaatan dengan cara merubah atau mengganti hukum nasional dalam upaya mewujudkan tujuan negara. Uraian di atas memberi pengertian antara lain bahwa politik hukum adalah arah pembangunan hukum yang berpijak pada sistem hukum nasional untuk mencapai tujuan dan cita-cita negara atau masyarakat bangsa. $^{2}$ Pembangunan harus dilandasi cita-cita dan memprioritaskan penghapusan hukum yang tidak berkeadilan yang selama ini hidup dalam tatanan sosial masyarakat serta melanggar hak asasi manusia.

Dalam rangka mewujudkan masyarakat adil makmur berdasarkan Pancasila dan Pasal 33 UUD 1945 menjadi marwah dalam pembangunan perekonomian Indonesia sekaligus upaya bersama dalam azas kekeluargaan, maka perlu dilakukan pembangunan ekonomi nasional yang berkelanjutan dengan

${ }^{1}$ Gustav Radbruch dalam Satjipto Raharjo, IImu Hukum, 2000, Jakarta, Citra Aditya Bakti, hlm. 19.

${ }^{2}$ Moh. Mahfud MD, Membangun Politik Hukum Menegakkan Konstitusi, 2010, Jakarta, Rajawali Press, hlm. 16. 
berlandaskan demokrasi ekonomi serta menciptakan iklim penanaman modal yang kondusif, promotif, memberikan kepastian hukum, keadilan, efisiensi dengan tetap memperhatian kepentingan ekonomi nasional. Pemerintah dengan ini mengesahkan Undang-Undang Nomor 25 Tahun 2007 tentang Penanaman Modal (selanjutnya disebut UUPM).

Kegiatan penanaman modal dimungkinkan terjadi perselisihan antara pemerintah dengan penanam modal asing. Oleh karena itu melalui Pasal 32 ayat (1) dan ayat (4) UUPM telah memberikan rambu-rambu dalam upaya penyelesaian sengketa antara pemerintah dengan penanam modal asing. Pasal 32 ayat (1) UUPM menyatakan bahwa dalam hal terjadi sengketa di bidang penananaman modal antara pemerintah degan penanam modal, para pihak terlebih dahulu menyelesaikan sengketa tersebut melalui musyawarah mufakat. Selanjutnya Pasal 32 ayat (4) UUPM menyatakan bahwa dalam hal terjadi sengketa penanaman modal antara pemerintah dengan penanam modal asing, para pihak akan menyelesaiakan sengketa tersebut melalui arbitrase internasional yang harus disepakati para pihak.

Persengketaan penanaman modal yang melibatkan pemerintah dengan penanam modal asing saat ini berada dalam hegemoni hukum arbitrase internasional, dimana pemerintah menyerahkan mekanismenya kepada International Centre for Settlement of Investment Disputte (ICSID). Indonesia tergabung dalam ICSID malalui ratifikasi Convention on the Settlement of Investment disputes Between States and National other States melalui UndangUndang Nomor 5 Tahun 1968 tentang Penyelesaian Perselisihan Antara Negara Dengan Warga Negara Asing Mengenai Penanaman Modal. Harmonisasi perjanjian internasional ke dalam hukum nasional suatu negara merupakan suatu proses yang penting dalam rangka menindaklanjuti perjanjian tersebut untuk diimplementasikan ke dalam wilayah suatu negara. ${ }^{3}$ Oleh karena itu secara politik ratifikasi ICSID menunjukan keterbukaan Indonesia dalam bidang penanaman modal, sedangkan secara ekonomi ratifikasi ICSID bertujuan untuk mendorong dan meningkatkan penanaman modal asing di Indonesia.

Sejak Indonesia meratifikasi konvensi ICSID tahun 1968 sampai saat tulisan ini dibuat, ada 7 (tujuh) kasus dimana pemerintah Indonesia berselisih dengan penanam modal asing. Berdasarkan data ICSID ketujuh perselisihan Indonesia dengan penanam modal asing yaitu Amco Asia Corporation (1981), Camex Asia Holding (2004), Kaltim Prima Coal (2007), Ravat Ali Rizvi (2011), Churchill Mining and Planet Mining Pty Ltd (2012), PT. Newmont Nusa Tenggara (2014), dan Oleovest Pte Ltd (2016). ${ }^{4}$

Dalam penyelesaian perselisihan bidang penanaman modal antara pemerintah Indonesia dengan penanam modal asing melalui ICSID ditengarahi membawa dampak kerugian besar bagi Indonesia. Kerugian tersebut dalam bentuk materiil maupun immaterill seperti jangka waktu penyelesaian yang lama, besaran

\footnotetext{
${ }^{3}$ Delfiyanti, Perjanjian ASEAN Comprehensive Investment Aggremennt (ACIA) Tahun 2009 Prospek dan Tantangan Bagi Indonesia, 2014, Semarang, Jurnal Masalah-Masalah Hukum, Volume 43 No. 4, HIm. 464-465.

${ }^{4}$ https://icsid.worldbank.org/en/Pages/cases/AdvancedSearch.aspx diakses tanggal 17 Februari 2017
} 
biaya menjadi permasalahan yang tak kalah penting bagi kita sebagai negara berkembang. Berangkat dari itu pengaturan penyeselesaian perselisihan penanaman modal antara pemerintah Indonesia dengan penanam modal asing hendaknya ditinjau kembali sebagai bentuk pembaharuan hukum dan pembangunan hukum nasional. Menurut Sajtipto Rahardjo dalam salah satu kritiknya ialah bahwa hukum itu sudah cacat sejak dilahirkan. ${ }^{5}$ Tidak mengherankan apabila Undang-Undang Penyelesaian Perselisihan Antara Negara Dengan Warga Negara Asing Mengenai Penanaman Modal banyak permasalahan, sehingga dapat berdampak buruk terhadap sistem hukum nasional.

Masuknya Indonesia sebagai anggota ICSID mengindikasikan penerimaan Indonesia terhadap sistem hukum global, oleh karena itu Pancasila sebagai ideologi bangsa harus mefilter guna menjaga marwah sistem hukum nasional dari pengaruh hukum global yang bersifat kapitalis, individualis bahkan cenderung neo liberalis. ICSID memaksa Indonesia menggunakan pranata hukum global untuk kepentingan mereka. Berdasarkan hal tersebut, maka pemerintah harus segera mencari solusi untuk mengatasi permasalahan guna menggapai tujuan negara. Scholten sebagaimana dikutip Sudikno Mertokusumo berpendapat bahwa hukum itu merupakan sistem terbuka karena berisi peraturan hukum yang sifatnya tidak lengkap dan tidak mungkin lengkap. ${ }^{6}$ Hukum harus mampu melakukan perubahan terhadap suatu keadaan yang tidak menguntungkan. Penyelesaian perselisihan penanaman modal saat ini dirasa tidak menguntungkan bagi Indonesia sebagai negara penerima modal, oleh karena itu hukum harus merespon keadaan yang demikian. Dalam perspektif ini hukum yang baik seharusnya menawarkan suatu keadaan yang lebih daripada hanya sekedar keadilan prosedural, hukum yang baik harus berkompeten dan juga adil, hukum semacam itu seharusnya mampu mengenali keinginan publik dan punya komitmen bagi tercapainya keadilan substantif. $^{7}$

\section{B. RUMUSAN MASALAH}

Dari latar belakang tersebut maka penulis mencoba merumuskan permasalahan sebagai berikut :

1. Bagaimanakah keuntungan dan kerugian pemerintah Indonesia dalam penyelesian perselisihan antara negara dengan warga negara asing mengenai penanaman modal melalui ICSID?

2. Bagaimanakah pembangunan penyelesian perselisihan antara negara dengan warga negara asing mengenai penanaman modal berbasis Pancasila?

\section{METODE PENDEKATAN}

${ }^{5}$ Satjipto Radahdjo, Hukum Dalam Jagat Ketertiban, 2006, Jakarta, UKI Press, HIm. VI

${ }^{6}$ Sudikno Mertokusumo, Mengenal Hukum Suatu Pengantar, 2003, Yogyakarta, Liberty, HIm.124.

${ }^{7}$ Philippe Nonet dan Philip Selznick, Hukum Responsif, 2015, Bandung, Nusamedia, HIm. 84. 
Secara harfiah metode berarti cara, oleh karenanya metode merupakan cara untuk menghasilkan ilmu yang diperoleh berdasarkan metode atau cara pendekatan tertentu untuk menjawab suatu pemasalahan. Sebagai produk ilmu maka segala pengetahuan yang telah didapat melalui metode keilmuan dan menjadi milik umum, artinya mengenai pengetahuan tersebut taka ada lagi pertentangan pendapat yang mendasar di kalangan masyarakat ilmuan. ${ }^{8}$ Oleh karenanya peneliti wajib tunduk pada aturan-aturan sebagai tolok ukur dalam bidang metodologi guna menghasilkan sains yang dapat dipertanggungjawabkan kebenarannya.

Makalah ini disusun menggunakan pendekatan sosio-legal ${ }^{9}$ yaitu pada prinsipnya adalah studi hukum, yang menggunakan pendekatan metodologi ilmu sosial dalam arti yang luas. ${ }^{10}$ Oleh Brian Z Tamanaha dikatakan bahwa hukun dan masyarakat memiliki bingkai yang disebut "The Law-Society Framework"11 yang memiliki karakteristik tertentu. Oleh karena itu sosiolegal memandang suatu permasalahan tidak hanya berdasarkan ilmu hukum semata, akan tetapi melalui berbagai pandangan ilmu lain yang dapat menyelesaikan suatu permasalahan secara komprehensif. Jadi studi hukum yang hanya menggunakan hukum positif sebagai basisnya gagal untuk memandu manusia keluar dari kesulitan dan perubahan yang memunculkan perkembangan baru. ${ }^{12}$ Dalam penulisan penelitian ini adalah penelitian kualitatif terhadap penyelesaian perselisihan negara dengan warga negara asing mengnai penanaman modal dalam sistem hukum nasional berbasis Pancasila.

\section{PEMBAHASAN}

Hukum merupakan aturan yang terus berkembang menyesuaikan jaman dan tidak pernah berhenti untuk menciptakan suatu gagasan baru guna mewujudkan keadilan, kemanfaatan dan kepastian. Hukum harus mampu merespon setiap permasalahan dengan memberikan solusi atas segala hiruk pikuk problematika kehidupan. Perkembangan pola pikir manusia tentang konsepsi hukum berdampak terhadap perubahan sistem hukum yang sangat fundamental sehingga hukum mampu membawa perubahan yang lebih baik. Sesungguhnya HIm 220.

${ }^{8}$ Liek Wilardjo, Realita dan Desiderta, 1990, Yogyakarta, Duta Wacara University Press,

${ }^{9}$ Mengutip pendapat Wheeler dan Thomas dalam Sulistyowati Irianto \& Shidarta, Metode Penelitian Hukum Konstelasi dan Refleksi, Yayasan Pustaka Obor Indonesia, Jakarta, 2013, studi sosiolegal adalah suatu pendekatan alternative yang menguji studi doctrinal terhadap hukum. Kata socio dalam sociolegal studies merepresentasi keterkaitan antar konteks di mana hukum berada (an interface with a context within which law exists). Itulah sebabnya mengepa ketika seorang peneliti sosiolegal menggunakan teori social untuk tujuan analisis, mereka sering tidak sedang bertujuan untuk memberi perhatian pa da sosiologi atau ilmu social yang lain, melainkan hukum dan studi hukum (banakar \& travers 2005). Sebagai suatu school of thought baru, studi ini melalui berbagai buku mutahir dan jurnal sudah menggambarkan teori, metode, dan topik-topik yang semakin mantap menjadi perhatian dari para penekunnya.

${ }^{10}$ ibid, HIm 175.

${ }^{11}$ Suteki, Reformasi Politik Hukum Tentang Hak Menguasai Negara Atas Sumer Daya Air Berbasis Nilai Keadilan Sosial, Disertasi, Undip, Semarang HIm. 32

${ }^{12}$ Sadjipto Rahardjo, Hukum Dalam Jagad Ketertiban, 2006, Jakarta, UKI Press, HIm 31. 
hukum tidak menabukan perubahan, tanpa perubahan hukum akan ditinggalkan masyarakat, pada tataran yang konkrit maka perubahan terjadi pada sistem dan peraturan hukum. ${ }^{13}$ Perubahan hukum tersebut merupakan respons terhadap permasalahan sosial masyarakat khususnya penyelesaian perselisihan antara negara dengan warga negara asing mengenai penanaman modal.

Pembangunan secara sederhana berarti merubah suatu keadaan yang kurang baik menjadi lebih baik atau yang tidak ada menjadi ada. Demikian pula penyelesaian perselisihan antara negara dengan warga negara asing mengenai penanaman modal di Indonesia dirasa kurang baik bahkan cenderung buruk. Hal ini disebabkan penerimaan pemerintah atas seluruh ketentuan mekanisme penyelesaian perselisihan penanaman modal asing melalui ratifikasi ICSID yang dirasa kurang tepat. Scohten sebagaimana dikutip Sudikno Mertokusumo berpendapat bahwa hukum itu merupakan sistem terbuka karena berisi peraturanperaturan hukum yang sifatnya tidak lengkap dan tidak mungkin lengkap. ${ }^{14}$ Oleh karena itu diperlukan adaya pembangunan hukum dengan membentuk hukum baru yang sesuai dengan nilai-nilai luhur bangsa Indonesia untuk melengkapi sistem hukum yang terbuka dan tidak lengkap.

\section{Keuntungan, Kerugian Sengketa Penanaman modal Asing di ICSID}

\subsection{Keuntungan dan kerugian Anggota ICSID}

Pembangunan perekonomian suatu negara tidak dapat dilakukan hanya mengandalkan peran pemerintah semata karena pembangunan perekonomian memerlukan modal sangat besar, oleh karena itu dibutuhkan penanam modal baik dalam negeri maupun asing guna mewujudkan pertumbuhan ekonomi nasional berkelanjutan. Indonesia selalu berupaya mendorong, membina, serta memberikan kepastian hukum terhadap penanaman modal asing di Indonesia melalui berbagai kebijakan guna mestimulasi dan mempermudah kegiatan penanaman modal. Salah satu upaya menarik minat, mendorong, dan membina penanam modal asing adalah mengesahkan konvensi IDSID melalui UU Penyelesaian Perselisihan Antara Negara Dengan Warga Negara Asing Mengenai Penanaman Modal. Konvensi itu sendiri bermakna suatu persetujuan formal yang bersifat multilateral dan tidak berurusan dengan kebijaksanaan tingkat tinggi (high policy). ${ }^{15}$

Hingga saat ini terdapat 161 negara yang tergabung bersama ICSID dan 8 negara diantaranya tidak pernah melakukan ratifikasi ICSID yaitu Belize, Republik Dominika, Etiopia, Guinea-Bissau, Republik Kirgizstan, Namibia, Federal Rusia, dan Thailand. ${ }^{16}$ Meskipun demikian negara-negara tersebut dapat meyelesaikan perselisihan penanaman modal asing ke ICSID, apabila para pihak

\footnotetext{
${ }^{13}$ Sadjipto Rahardjo, Hukum Progresif Sebuah Sintesa Hukum Indonesia, 2009, Yogyakarta, Genta Publishing, HIm 59.

${ }^{14}$ Sudikno Mertokusumo, Mengenal Hukum Suatu Pengantar, 2003, Yogyakarta, Liberty, HIm. 124.

${ }^{15} J o h n$ O'Brien International Law dalam Jawahir Thantowi, Hukum Dan Hubungan Internasional, 2016, Jogjakarta, UII Press, HIm 82.

${ }^{16}$ https://icsid.worldbank.org/en/Pages/about/Database-of-Member-States.aspx diakses tanggal 3 Maret 2017.
} 
menyepakatinya dalam bentuk perjanjian Bilateral Investment Treaty (BIT) antara satu negara dengan negara lainnya. BIT merupakan dasar hukum para pihak untuk mengajukan penyelesaian perselisihan penanaman modal asing di ICSID selain ratifikasi konvensi.

Pemerintah meratifiasi konvensi ICSID pada tahun 1968 disusul dikeluarkannya Keputusan Presiden Nomor 34 Tahun 1981 tentang pengesahan Convention on the Recognition and Enforcement of Foreign Arbitral Awards dan Peraturan Mahkamah Agung Nomor 1 Tahun 1990 tentang Tata Cara Pelaksanaan Putusan Arbitrase Asing. Dengan adanya UU Peryelesaian Perselisihan Penanaman Modal maka proses penyelesaian sengketa yang melibatkan pemerintah dengan penanam modal asing wajib tunduk dan patuh pada ketentuan International Centre For Settlemen Of Investment Disputes (ICSID). Implikasi Indonesia dalam ratifikasi ICSID, maka negara wajib menundukan diri terhadap seluruh muatan konvensi, termasuk penyelesaian perselisihan yang diajukan pada ICSID dan harus mendapatkan persetujuan oleh kedua belah pihak. Hal ini tentunya tidak berlebihan mengingat ratifikasi menunjukan tunduknya sebagian hukum nasional terhadap hukum internasional, dalam konteks ini ICSID sebagai pedoman tertulis dalam meyelesaikan perselisihan antara negara dengan warga negara asing mengenai penanaman modal.

Teori economics analysis of law dari Richard Posner yang menitik beratkan pada penerapan prinsip-prinsip ekonomi dalam menganalisis persoalan hukum yang menggunakan asas kemanfaatan sangat tepat diterapkan dalam rangka mengkaji penyelesaian perselisihan antara negara dengan warga negara asing mengenai penanaman modal karena hukum tidak mampu berdiri sendiri, dalam artian bahwa hukum selalu dipengaruhi oleh faktor- faktor lainnya termasuk ekonomi. Dengan pendekatan ekonomi diharapkan memberikan efisiensi dan efetifitas yang ideal dalam pembentukan peraturan perundangundangan sekaligus mefilter sistem hukum global yang tidak sesuai dengan sistem hukum Pancasila. Oleh arena itu prinsip hukum dan ekonomi tidak mampu berdiri sendiri, akan tetapi menjadi satu kesatuan sebagaimana prinsip Equilibrium Composition yaitu prinsip ini berusaha mendekatkan esensi perpaduan kepentingan baik untuk perbaikan hukum nasional dan internasional bahkan dalam hal mengharmonisasi kedua hukum tersebut pada titik dekatnya, sehingga dapat mempertumukan keseimbangan komposisi (equalibrium composition) kepentingan dan tujuan bersama. ${ }^{17}$

Berkaitan dengan hal itu, analisis ekonomi dalam hukum seperti ini dikenal dengan ide wealth maximization atau dalam istilah Posner "kaldor-hics" dimana perubahan aturan hukum dapat meningkatkan efisiensi jika keuntungan pihak yang menang melebihi kerugian pihak yang kalah dan pihak yang menang dapat memberikan kompensasi kerugian bagi pihak yang kalah, sehingga pihak yang kalah tersebut tetap menjadi lebih baik. Dalam konteks ini, Posner menilik salah satu segi keadilan yang mencakup bukan sekedar keadilan distributif dan korektif. Posner menekankan "pareto improvement" di mana tujuan dari

${ }^{17}$ Fajar Sugianto, Economic Approach to Law, 2015, Jakarta, Kencanaprenada Media Group, HIm. 118. 
pengaturan hukum dapat memberi masukan berharga bagi keadilan dan kesejahteraan sosial. ${ }^{18}$

Keikutsertaan Indonesia sebagai Anggota ICSID ada nilai positif maupun negatifnya, meskipun demikian pada dasarnya arbitrse sebagai lembaga penyelesaian perselisihan memiliki beberapa prinsip. Menurut Munir Fuadi ${ }^{19}$ arbitrase menganut beberapa prinsip sebagai berikut :

a) Efisien : efisien dalam hubungannya dengan waktu dan biaya jika dibandingkan dengan penyelesaian sengketa melalui badan-badan peradilan umum.

Bahwa penyelesaian perselisihan penanaman modal di ICSID telah mematok biaya US\$ 100.000-150.000 atau sekitar Rp 2 miliar (Pasal 60 konvensi dan pasal 14 ayat (3) peraturan administrasi keuangan). Penyelesaian perselisihan di ICSID memakan waktu relatif singkat yaitu 2-3 tahun.

b) Accessiblity : penyelesaian sengketa penanaman modal melalui arbitrase harus terjangkau dalam arti biaya, waktu dan tempat.

Penyelesaian perselisihan penanaman modal asing membutuhkan biaya sekitar Rp. 104 miliar per satu kasus. Biaya tersebut digunakan untuk membayar kebutuhan administrasi, akomodasi, pengacara handal serta penyelesian melalui ICSID diselesaikan di New York, Amerika Serikat.

c) Proteksi para pihak : terutama pihak yang tidak mampu, misalnya untuk mendatangkan saksi ahli atau untuk menyewa pengacara terkenal harus dapat perlindungan yang wajar.

Dalam penyelesaian perselisihan di ICSID tidak dikenal dengan adanya prodeo atau biaya cuma-cuma, sehingga pihak yang tidak mampu tidak akan bisa mengakses keadilan di ICSID.

d) Final dan binding : keputusan arbitrase haruslah final dan binding kecuali memang para pihak tidak mengehendaki demikian atau jika ada alasan-alasan yan berhubungan dengan due process.

Putusan Arbitrase ICSID selama ini masih dapat dibatalkan melalui prosedur permohonan pembatalan ke Dewan Arbitrase ICSID, sehingga dimungkinkan proses penyelesaian perselisihan membutuhkan waktu yang lama.

e) Fair and just : keputusan arbitrase haruslah dilakukan secara tepat dan adil untuk para pihak yang berseketa dan sebagainya.

Pada dasarnya menilai ketepatan dan dalam keadilan suatu putusan sangat sulit, karena keadilan bersifat subjektif dan memiliki sudut pandang yang berbeda-beda, sehingga keadilan berdifat abstrak.

f) Sesuai dengan sense of justice (keadilan) bagi masyarakat : dengan demikian adanya arbitrse akan lebih menjamin unsur deterrent

\footnotetext{
${ }^{18}$ Nicholas Mercuro dan Steven G Medumo, Economic and The Law : From Posner to Post-modernism, 1999 New Jersey, Princenton University Press, , Hlm 58-59.

${ }^{19}$ Munir Fuady, Arbitrase Nasional : Alternatif Penyelesaian Sengketa Bisnis, 2000, Bandung, Citra Aditya Bakti, HIm. 93-94.
} 
(pencegahan) dari pelanggar dan sengketa lebih lanjut akan dapat dicegah.

Sebelum suatu perkara di persidangkan oleh majelis arbitrse para pihak dikasih kesempatan untuk melakukan konsiliasi agar perkara ini dapat selesai tanpa maju ke majelis arbitrase ICSID.

g) Kredibilitas : para arbiter dan badan arbitrase yang bersangkutan haruslah orang-orang yang diakui kredibilitasnya sehingga keputusan dan ketepatannya akan lebih dihormati.

Selama ini negara-negara anggota ICSID sangat menghormati setiap putusan ICSID, karena majelis arbitrase ICSID adalah pihak-pihak yang kompeten dalam bidang penanaman modal.

Prinsip-prinsip arbitrase tersebut menjadi penuntun penyelesaian perselisihan penanaman modal asing di Indonesia, akan tetapi prinsip-prinsip tersebut terkadang berbeda dengan kenyataannya, demikian halnya dengan penyelesaia perselisihan di ICSID. Oleh karena itu penyelesaian perselisihan penanaman modal asing di ICSID memiliki beberapa keuntungan dan kerugian bagi pemerintah Indonesia. Keuntungan dan kerugian bagi pemerintah Indonesia antara lain kerahasiaan, proses cepat, kebebasan memilih arbiter, putusan abitrase bersifat final dan mengikat, pengakuan dan pelaksanaan putusan arbitase internasional. Sedangkan kerugian bagi Indonesia adalah biaya beracara yang cukup besar, gugatan yang diajukan sangat besar. ${ }^{20}$

\subsection{Sengketa Penanaman Modal Asing di ICSID}

Persengketaan pemerintah dengan penanam modal merupakan hal yang tidak diinginkan oleh kedua belah pihak dalam kerjasama penaman modal, akan tetapi hal tersebut tidak dapat dihindari karena bagian risiko yang harus ditanggung. Penyelesaian sengketa penanaman modal asing melalui ICSID merupakan bentuk penyelesaian sengketa yang digunakan bagi penanam modal asing yang bersengketa dengan suatu negara penerima modal. ${ }^{21}$ Bentuk penyelesaian sengketa pemerintah dengan penanam modal asing sebenarnya dapat diselesaikan melalui jalur lembaga peradilan di tempat investasi itu berada, akan tetapi penanam modal asing pada umumnya kurang percaya terhadap penegakan hukum yang dilakukan oleh lembaga peradilan, mengingat yang bersengketa adalah pemerintah dengan penanam modal asing yang sekiranya pemerintah suatu negara dapat mengintervensi penegakan hukum dalam penyelesaian sengketa antara pemerintah dengan penanam modal asing.

Putusan yang mengalahkan dan memerintahkan pemerintah untuk membayar ganti rugi dinilai sangat merepotkan dan membebani keuangan

\footnotetext{
20 Aldo Rico Deraldi, Analisis Keuntungan dan Kerugian Indonesia Terkait Opsi Penyelesaian Sengketa Investasi Indonesia Dengan Churchill Mining Plc di ICSID, 2015, Yogyakarta, Jurnal Penelitian Hukum, Volume 2, Nomor 2, HIm. 119-122.

${ }^{21}$ Sophie Dhinda Aulia Brahmana, Penyelesaian Sengketa Penanaman Modal Melalui Arbitrase Internasional (Studi Kasus Pencabutan Ijin Usaha Pertambangan Churchill Mining oleh Pemerintah Daerah Kabupaten Kutai Timur), 2013, Medan, Jurnal Hukum Ekonomi, Feb-Mei, HIm. 2
} 
negara. ${ }^{22}$ Selain itu penyelesaian sengketa dalam bidang penanaman modal di ICSID memerlukan biaya yang sangat besar guna membayar biaya administrasi, arbiter serta advokat yang ahli dalam bidang penyelesaian sengketa antara pemerintah dengan penanam modal asing di ICSID. Hasil kajian Komisi Eropa awal 2015 melaporkan biaya rata-rata untuk berperkara di arbitrase internasional adalah sekitar 8 juta dollar AS. Bila nilai tukar 1 dollar AS adalah Rp. 13.000 maka biaya yang dikeluarkan pemerintah sekitar Rp. 104 miliar. Bagi negara berkembang seperti Indonesia dana biaya Rp. 104 miliar tentunya sangat besar dan memberatkan perekonomian pemerintah Indonesia. Biaya ini sekitar $75 \%$ untuk membayar biaya pengacara asing dan saksi ahli serta sisanya untuk membayar biaya arbiter dan sektertariat arbitrase. ${ }^{23}$

Hingga saait ini ICSID menerima 615 kasus perselisihan penanaman modal asing dimana 216 kasus dinyatakan masih ditunda dan 399 kasus sudah diputus. ${ }^{24}$ Sementara itu penyelesaian perselisihan penanaman modal asing di ICSID dalam waktu 5 tahun terakhir mengalami kenaikan, dimana setiap tahunnya ICSID menerima perselisihan penanaman modal asing rata-rata lebih dari 30 kasus setiap tahun mulai 2011-2016, bahkan 2017 tercatat sudah ada 9 kasus perselisihan yang masuk ke ICSID. ${ }^{25}$ Oleh karena itu Indonesia sebagai salah satu negara penerima modal asing perlu mewaspadai seringnya penanam modal asing membawa perselisihan ke ICSID.

Sejak Indonesia meratifikasi konvensi ICSID tahun 1968 sampai saat tulisan ini dibuat, ada 7 (tujuh) kasus dimana pemerintah Indonesia berselisih dengan penanam modal asing. Berdasarkan data ICSID ketujuh perselisihan Indonesia dengan penanam modal asing yaitu Amco Asia Corporation (1981), Camex Asia Holding (2004), Kaltim Prima Coal (2007), Ravat Ali Rizvi (2011), Churchill Mining and Planet Mining Pty Ltd (2012), PT. Newmont Nusa Tenggara (2014), dan Oleovest Pte Ltd (2016). ${ }^{26}$ Berdasaran data tersebut 7 perkara perselisihan penanaman modal asing yang melibatkan Indonesia yang diputus ICSID 1 ditunda dan 6 perkara hingga putusan akhir/kesimpulan.

Anggota ICSID yang mencapai 161 negara berharap dengan keikutsertaan sebagai anggota ICSID akan membawa dampak positif untuk mendorong dan meningkatkan pertumbuhan perekonomian suatu negara. Hal tersebut pada dasarnya tidak menjamin setiap negara yang melakukan ratifikasi ICSID akan meningkatkan pertumbuhan perekonomiannya. Hal ini didasarkan oleh keberadaan negara bukan anggota ICSID, akan tetapi memiliki pertumbuhan perekonomian di atas rata-rata diantaranya adalah India, Brazil, Afrika Selatan. Pada tahun 2015 perekonomian India adalah terbesar ke tujuh, sementara itu

22 Huala Adolf, Sengketa Penanaman Modal antara Investor Melawan Pemerintah Indonesia di Arbitrase ICSID, 2014, Bandung, Jurnal Ilmu Hukum Volume 1 No. 3, HIm. 426.

${ }^{23}$ Huala Adolf, dan An An Chandrawulan, Mekanisme Penyelesaian Sengketa Penanaman Modal, 2015, Bandung, Keni Media, HIm 97.

${ }^{24}$ https://icsid.worldbank.org/en/Pages/cases/AdvancedSearch.aspx diakses tanggal 3 Maret 2017

${ }^{25}$ Ibid, diakses tanggal 3 Maret 2017.

${ }^{26}$ Loc. Cit. 
Brazil menempati urutan ke Sembilan dan Afrika Selatan menempati urutan ke dua puluh lima ekonomi dunia meskipun tidak menjadi anggota ICSID.

Negara India, Brazil dan Afrika Selatan bisa menjadi contoh bagi Indonesia karena selain pertimbangan di atas Indonesia adalah negara yang memiliki sumber daya manusia yang mumpuni, sumber daya alam yang melimpah, pangsa pasar yang menjanjikan, upah buruh yang murah, kebijakan pemerintah yang semakin baik, pemberian fasilitas berupa pembebasan pajak, fasilitas keimigrasian, fasilitas perizinan impor, penggunaan hak atas tanah yang mencapai 95 tahun adalah beberapa kelebihan untuk menarik bagi penanam modal asing untuk mempercayakan dananya di Indonesia. Berdasarkan berbagai pertimbangan tersebut, sudah saatnya pemerintah menentukan sikap untuk keluar dari keanggotaan ICSID guna menunjukan kembali kedaulatan hukum nasional.

\section{Pembangunan Hukum Penyelesaian Perselisihan Penanaman Modal}

\section{Asing}

\subsection{Pengertian Pembangunan Hukum Nasional}

Hukum adalah suatu institusi yang bertujuan mengantarkan manusia kepada kehidupan yang adil, sejahtera dan membuat manusia bahagia. ${ }^{27}$ Hukum nasional dibuat, dibangun dan dikembangkan guna menata kehidupan dan kemasyarakatan di seluruh Indonesia. Hukum nasional didayagunakan untuk merekayasa sendi-sendi kehidupan rakyat. ${ }^{28}$ Oleh karena itu pembangunan hukum adalah usaha terus menerus dilakukan guna melakukan perubahan dari suatu keadaan yang kurang baik menjadi lebih baik guna memberikan keadilan kesejahteraan dan kebahagiaan manusia. Hal ini terkait erat dengan seluruh aspek pembangunan hukum nasional khususnya penyelesaian perselisihan penanaman modal asing. Hukum nasional itu sendiri adalah hukum atau peraturan periundang-undangan yang dibentuk dan dilaksanakan untuk mencapai tujuan dasar dan cita hukum suatu negara. ${ }^{29}$ Dalam konteks ini maka pembentukan hukum nasional seharusnya berlandarkan pada Pancasila dan pembukaan UUD 1945 sebagai sumber hukum nasional.

Pada dasarnya sistem hukum adalah suatu kesatuan yang terdiri dari unsurunsur yang mempunyai interkasi satu sama lain dan bekerjasama untuk mencapai tujuan kesatuan tersebut. ${ }^{30}$ Lebih lanjut Satjipto Rahardjo menyatakan bahwa sistem hukum adalah suatu kesatuan yang bersifat kompleks yang terdiri dari bagian-bagian yang berhubungan satu sama lain. ${ }^{31}$ Oleh karena itu dalam kesatuan sistem hukum yang terdiri dari bagian-bagian hukum yang saling berkaitan harus saling menguatkan antara satu dengan yang lainnya guna mencapai tujuan hukum yaitu keadilan, kemanfaatan (utilitas) serta ketertiban

${ }^{27}$ Sadjipto Rahardjo, Op.cit, HIm. 2.

${ }^{28}$ Soetandyo Wignjosoebroto, 2002, Jakarta, Elham dan Huma, HIm. 173.

${ }^{29}$ Moh. Mahfud MD, Membangun Politik Hukum Menegakkan Konstitusi, 2010, Jakarta, Rajawali Press, HIm. 21.

${ }^{30}$ Sudikno Mertokusumo, Op. Cit, HIm. 122.

${ }^{31}$ Satjipto Rahardjo, Ilmu Hukum, 1982, Bandung, Alumni, HIm. 89. 
masyarakat. Terjadinya berbagai permasalahan dalam penyelesaian perselisihan penanaman modal asing merupakan contoh sistem hukum yang kurang bagus.

Friedman membagi sistem hukum menjadi tiga komponen yaitu substansi (substance) atau isi hukum yaitu peraturan-peraturan, struktur hukum (structure) sistem yudisial atau penegak hukum dan kultur (culture) atau budaya hukum yakni elemen sikap dan nilai sosial. Dari ketiga komponen sistem hukum yang disampaikan Friedman, penulis membatasi diri pada pembahasan pada substansi hukum semata. Seluruh komponen-komponen tersebut satu sama lain saling bertuhungan dan saling membutuhkan untuk mewujudkan tujuan hukum. Pembentukan UU Penyelesaian Perselisihan Antara Negara Dengan Warga Negara Asing Mengenai Penanaman Modal Asing merupakan contoh substansi hukum yang kurang tepat apabila diterapkan di Indonesia. Hal ini dikarenakan substansi atau isi hukum undang-undang penyelesaian perselisihan penanaman modal asing seluruhnya berasal dari negara hukum yang bersifat capitalism, liberalism, dan individualism. Hukum yang kapitalism, liberalism dan individualism memiliki tugas pokok yaitu menjaga dan menjamin agar kemerdekaan dan kebebasan individu memperoleh kedudukan yang mapan. ${ }^{32} \mathrm{Hal}$ ini ketika diterapkan di indonesia yang memiliki karakteristik hukum sendiri yang sangat berbeda dengan negara hukum yang bersifat liberalis dan individualis, sekiranya hukum yang demikian tetap diterapkan maka dapat menimbulkan permasalahan baru dalam dalam masyarakat.

Pembangunan hukum bukan hanya sekedar mengganti atau merubah suatu aturan semata, akan tetapi harus menyesuaikan dengan kondisi masyarakat sebagai pengguna produk hukum diciptakan, karena pada dasarnya hukum dibuat untuk manusia dan bukan sebaliknya. Bertitik tolak dari hal tersebut, Barda Nawawi Arief ${ }^{33}$ menyatakan kalau bertolak dari ketiga nilai/pilar eseimbangan Pancasila maka pendekatan yang seyogyanya ditempuh dalam sistem hukum Pancasila adalah :

a. Pendekatan yang berwawasan nilai-nilai ketuhanan (bermoral religious)

b. Pendekatan yang berwawasan nilai-nilai kemanusiaan (humanistik)

c. Pendekatan yang berwawasan nilai-nilai kemasyarakatan (nasionalistik, demokratik, berkeadilan sosial).

Soetandyo Wigjosoebroto ${ }^{34}$ menyatakan bahwa pembangunan hukum diupayakan untuk menemukan sarana yang ampuh untuk membangun masyarakat ini didasarkan pada pertimbangan bahwa hukum nasional yang baik dalam hal kebenaran isinya maupun dalam hal kekuatan penegakkannya. Pada kondisi yang demikian pada dasarnya hukum dikonsepsikan sebagai sarana merubah masyarakat (sosial engenering) yang didasarkan pada subtansi peraturan perundang-undangan yang baik serta aparatur penegak hukum sebagai komponen

\footnotetext{
${ }^{32}$ Satjipto Rahardjo, Negara Hukum yang Membahagiakan Rakyatnya, 2009, Yogyakarta, Genta Publishing, HIm. 23.

${ }^{33}$ Barda Nawawi Arief, Pembangunan Sistem Hukum Nasional Indonesia, 2015, Semaran, Pustaka Magister, HIm. 17.

${ }^{34}$ Soetandyo Wignjosoebroto, Op.Cit, HIm. 174.
} 
struktur hukum yang baik pula, akan tetapi tidak diimbangi oleh kompnen culture atau budaya hukum.

Sementara itu Moh. Mahfud MD ${ }^{35}$ politik hukum adalah legal policy atau arah hukum yang akan diberlakukan oleh negara untuk mencapai tujuan negara yang bentuknya dapat berupa pembuatan hukum baru dan menggantikan hukum lama. Penulis berpendapat bahwa pada esensinya politik hukum sama dengan pembangunan hukum yaitu suatu tindakan yang dilakukan oleh pemerintah untuk membentuk hukum baru sebagai pengganti hukum lama yang sudah tidak sesuai dengan kebutuhan masyarakat untuk mencapai tujuan negara. Tujuan negara pada umumnya mengacu pembukaan UUD 1945 yaitu:

a. Melindungi segenap bangsa Indonesia dan seluruh tumpah darah Indonesia;

b. Memajukan kesejahteraan umum;

c. Mencerdaskan kehidupan bangsa;

d. Ikut melaksanakan ketertiban dunia yang berdasarkan kemerdekaan, perdamaian abadi dan keadilan sosial.

Tujuan negara tersebut harus dilaksanakan oleh negara berlandaskan kepada Pancasila sebagai bintang pemandu terhadap pembangunan hukum di Indonesia yaitu Ketuhanan Yang Maha Esa, Kemanusian yang adil dan beradap, Persatuan Indonesia, Kerakyatan yang dipimpin oleh hikmat kebijaksanaan dalam permusyawaratan perwakilan dan Keadilan sosial bagi seluruh rakyat Indonesia.

Pembangunan hukum pada dasarnya mengindikasikan adanya kesenjangan masyarakat dalam suatu peraturan perundang-undangan yang terlalu dalam, sehingga kebutuhan pembangunan hukum tidak dapat dielakan. Kesenjangan hukum tersebut dapat terjadi sejak proses pembuatannya maupun kondisi masyarakat di suatu tempat telah berubah, sehingga hukum harus mengikuti perubahan masyarakat. Kesenjangan hukum dialamai oleh UU penyelesaian perselisihan antara negara dengan warga negara asing mengenai penanaman modal, karena sejak kelahiran undang-undang tersebut ditunggangi oleh kepentingan hukum global yang bersifat kapitalis, liberalis dan individualis. Kesenjangan tersebut tampak jelas dengan perbedaan-perbedaan dari faktor ekonomi, politik, sosial, maupun budaya, sehingga hukum yang demikian perlu dilakukan perubahan guna mewujudkan sistem hukum nasional yang lebih baik dengan naungan Pancasila.

\subsection{Penyelesaian Perselisihan Penanaman Modal Asing Berbasis}

\section{Pancasila}

Bagi penulis perselisihan adalah perbedaan pola pikir dalam melihat suatu keadaan. Selama ini banyak terjadi permasalahan dalam bidang peyelesaian perselisihan antara negara dengan warga negara asing mengenai penanaman modal. Munculnya perselisihan dalam bidang penanaman modal antara negara dengan warga negara asing merupakan risiko pemerintah akibat masuknya

\footnotetext{
${ }^{35}$ Moh. Mahfud MD, Op.Cit, HIm. 5.
} 
penanam modal asing ke Indonesia. Penanaman modal pada dasarnya bertujuan untuk saling mendapatkan keuntungan, oleh karena itu dibentuk Undang-Undang Nomor 25 Tahun 2007 tentang Penanaman Modal. Penanaman modal asing adalah kegiatan menanam modal untuk melakukan usaha di wilayah negara Republik Indonesia yang dilakukan oleh penanam modal asing sepenuhnya maupun yang berpatungan dengan penanam modal dalam negeri.

Pembentukan Bank Dunia (World Bank), IMF (International Monetary Fund), dan GATT (General Agreement Tariff anf Trade) merupakan jawaban untuk melanggengkan kapitalisme. ${ }^{36}$ Demikian halnya dengan ICSID yang merupakan badan otonom Bank Dunia yang memiliki kewenangan menyelesaikan perselisihan penanaman modal yang melibatkan negara dengan warga negara asing.

Terbentuknya ICSID adalah akibat dari situasi perekonomian dunia pada waktu itu yaitu khususnya dikala beberapa negara berkembang yang melakukan tindakan sepihak terhadap investor asing di dalam wilayahnya yang mengakibatkan konflik-konflik ekonomi yang dapat menimbukan sengketa ekonomi berubah menjadi sengketa politik bahkan sengketa terbuka (perang). Tindakan sepihak negara-negara berkembang ini adalah nasionalisasi perusahaan milik investor asing (di Indonesia misalnya adalah kasus nasionalisasi perusahaan-perusahaan perkebunan terbakau milik Belanda), eksploitasi dan tindakan pengibirian perusahaan asing lainnya. ${ }^{37}$ Oleh karenanya dalam pelaksanaan penanaman modal dimungkinkan terjadi perselisihan yang melibatkan negara selaku pihak pemberi ijin dengan penanam modal asing. Hal ini merupakan suatu peristiwa yang tidak diinginkan oleh kedua belah pihak, akan tetapi apabila hal tersebut terjadi, maka negara harus memberikan solusi guna menjawab permasalahan dalam bidang penanaman modal. Oleh karena itu melalui Pasal 32 ayat (1) dan ayat (4) UUPM telah memberikan aturan penyelesaian perselisihan antara negara dengan penanam modal asing.

Indonesia sudah menjadi bagian dari masyarakat global yang tergabung dalam berbagai organisasi internasional dan terikat pada beberapa perjanjian internasional. ${ }^{38}$ Penyelesaian sengketa dalam bidang penanaman modal melalui arbitrase internasional akan diselesaikan oleh badan otonom bernama International Centre for Setlement of Investment Dispute (ICSID) yang berada di bawah payung Bank Dunia yang berpusat di New York Amerika Serikat. ICSID bukan badan arbitrase komersial seperti ICC (International Chamber Commerce) melainkan suatu badan arbitrase yang menyediakan mekanisme penyelesaian sengketa investasi antara investor asing dengan salah satu negara anggota

${ }^{36} \mathrm{FX}$. Adji Samekto, Kapitalisme, Modernisasi, dan Kerusakan Lingkungan, 2008, Yogyakarta, Genta Press, HIm 50.

${ }^{37}$ Huala Adolf, Arbitrase Komersial Internasional, 2002, Jakarta, Rajawali Pers, HIm. 36.

${ }^{38}$ Widhayani Dian Pawestri, Dialektika perlindungan Kepentingan Nasional Berdasarkan Konstitusi Ekonomi Dengan Basic Prinsiple Dalam Bilateral Investment Treaties, 2016, Surabaya, Jurnal Yuridika, Volume 31 No. 1 HIm.102 
ICSID $^{39}$. Penyelesaian Sengketa dalam bidang penanaman modal melalui ICSID adalah hasil ratifikasi Indonesia terhadap Convention on the settlement of Investment Dispute between State and Nationals of other States melalui UndangUndang Nomor 5 Tahun 1968 tentang penyelesaian Perselisihan Antara Negara dengan Warga Negara Asing mengenai Penanaman Modal.

Indonesia bergabung sebagai anggota ICSID dilatarbelakangi oleh keadaan, diamana pada tahun 1960 an Indonesia sebagai negara baru merdeka dan sedang giat-giatnya membangun perekonomian nasional yang salah satunya mengundang penanam modal asing untuk berinvestasi di Indonesia. Salah satu cara guna menarik penanam modal asing guna melakukan investasi di Indonesia adalah dengan meratifikasi konvensi ICSID. Pertimbangan keikutsertaan Indonesia dalam ICSID dapat dilihat dalam konsideran UU No. 5 Tahun 1968 yaitu untuk mendorong dan membina penanam modal asing di Indonesia, Republik Indonesia sebagai anggota Bank International untuk rekonstruksi dan pembangunan (International Bank for Reconstruction and Development) serta keanggotaan Indonesia dalam Dana Moneter Internasional (International Monetary Found) memiliki kepentingan dalam hubungan internasional guna mendapatkan bantuan keuangan oleh lembaga-lembaga keuangan dunia.

UU Penyelesaian Perselisihan Antara Negara Dengan Warga Negara Asing Mengenai Penanaman Modal memanjakan penanam modal asing dan dijadikan senjata untuk menakut-nakuti pemerintah Republik Indonesia dengan membawa setiap permasalahan penanaman modal asing ke ICSID. Bagi penulis tergabungnya Indonesia sebagai anggota ICSID hingga sekarang sesungguhnya patut disayangkan dan sekiranya tidak perlu dilakukan, mengingat posisi Indonesia sebagai tuan rumah dalam bidang penanaman modal yang memiliki kedaulatan hukum sekaligus strata lebih tinggi daripada penanam modal asing. Selain mengajak berpikir ulang untuk meneruskan BIT, Guru Besar Hukum Internasional FH UI Prof. Hikmahanto Juana juga mengimbau Indonesia keluar dari Internasional Centre for the Settlement of Investment Disputes (ICSID). ${ }^{40}$ Pada dasarnya Indonesia memiliki nilai tawar lebih dibandingkan penanam modal asing, hal ini dapat terlihat dengan banyaknya sumber daya manusia yang mumpuni, kekayaan sumber daya alam, pangsa pasar yang menggiurkan.

Masuk atau keluarnya Indonesia sebagai negara anggota ICSID pada dasarnya adalah hak mutlak untuk menentukan kedaulatan hukum yang dimiliki oleh suatu negara. Menurut teori kedaulatan negara Jean Bodin bahwa hukum itu adalah penjelmaan dari kehendak negara, negaralah yang menciptaan hukum dan negara adalah satu-satunya sumber hukum yang memiliki kedaulatan. ${ }^{41}$ Negara adalah institusi yang paling berhak untuk menentukan arah kebijakan pembentukan hukum, termasuk hukum penyelesaian perselisihan antara negara dengan warga negara asing mengenai penanaman modal. Lebih lanjut bahwa

\footnotetext{
${ }^{39}$ Nurnaningsih Amriani, Penerapan Prinsip Keterbukaan Atas Putusan Arbitrase ICSID di Indonesia dan Perbandingannya dengan Beberapa Negara, 2016, Medan, Jurnal Hukum dan Peradilan Volume 5 No. 1, HIm. 116.

${ }^{40}$ https://hukumonline.com/berita/baca/lt5145a99083b4d/guru-besar-hukum-mintaindonesia-keluar-dari-icsid diakses tanggal 10 Maret 2017

${ }^{41}$ Bernard L Tanya, at al, Op Cit, HIm. 60.
} 
penyelesaian perselisihan penanaman modal yang melibatkan negara dengan warga negara asing di ICSID kurang adil dan seimbang, karena kedaulatan negara penerima penanaman modal sebagai tuan rumah tersandera oleh sistem hukum global yang bersifat kapitalis liberalis dan individualis. Keadaan yang demikian bagi penulis dirasa kurang tepat, sehingga kedaulatan hukun nasional wajib dikembalikan.

Pengakhiran perjanjian internasional merupakan sikap politik sekaligus tindakan hukum yang memiliki konsekuensi tersendiri. Oleh karena itu kekuasaan membuat hukum pada prinsipnya adalah hukum harus menjadi sarana untuk mencapai tujuan bernegara, oleh karena itu pembentukan hukum nasional didasari oleh nilai-nilai luhur bangsa Indonesia yang terdapat pada Pancasila. Menurut Abdul Hakim Garuda Nusantara sebagaimana dikutip Moh. Mahfud MD menyatakan bagaimanapun hukum di Indonesia harus mengacu kepada cita-cita masyarakat bangsa, yakni tegaknya negara hukum yang demokratis dan berkeadilan sosial. ${ }^{42}$ Demikian pula dengan pembentukan peraturan tentang penyelesaian perselisihan penanaman modal sebagai upaya mewujudkan pembangunan perekonomian nasional yang berkeadilan sosial harus mengacu kepada tujuan negara hukun.

Penerapan ideologi Pancasila dalam pendekatan pengambilan kebijakan mengenai bidang penyelesaian perselisihan penanaman modal asing seharusnya mempertimbangkan aspek keuntungan dan kerugian bagi Indonesia selaku tuan rumah penanaman modal, sehingga bergabungnya Indonesia di ICSID membawa dampak positif bagi perekonomian Indonesia. Namun apabila bergabungnya Indonesia pada ICSID membawa dampak negatif, maka perlu dikaji kembali kenaggotaan Indonesia pada ICSID. Lebih lanjut bergabungnya Indonesia sebagai negara anggota ICSID akan memberikan beban keuangan negara berupa pembayaran biaya berperkara yang sangat mahal dan harus ditanggung oleh para pihak yang bersengketa di ICSID termasuk Indonesia. Biaya tersebut digunakan untuk membayar administrasi, akomodasi, transportasi serta honorarium lawyer yang ahli dalam bidang penanaman modal. Hal ini tentunya akan membebani keuangan negara pabila Indonesia sering bersengketa di ICSID dan apabila Indonesia kalah maka keuangan negara akan terforsir untuk membayar ganti rugi.

Setiap pembentukan peraturan perundang-undangan wajib didasari oleh keadilan sosial sebagai bagian tidak terpisahkan dari Pancasila yang menjadi acuan dalam penbentukan Undang-Undang Penyelesaian Perselisihan Aantara Negara Dengan Warga Negara Asing Mengenai Penanaman Modal sekaligus meratifikasi konvensi ICSID. Isi konvensi ICSID seluruhnya berasal dari hukum global yang bersifat kapitalis, liberalis, dan individualis, oleh karena itu konvensi tersebut tidak sesuai dengan nilai-nilai Pancasila sebagai pandangan hidup bangsa Indonesia. Undang-Undang Penyelesaian Perselisihan Penanaman Modal Asing harus sesegera mungkin direvisi guna meminimalisir kerugian keuangan negara akibat tuntutan penanam modal asing ke ICSID memberikan keadilan sosial bagi

\footnotetext{
${ }^{42}$ Moh. Mahfud MD, Membangun Politik Hukum Menegakkan Konstitusi, 2010, Jakarta, Rajawalipress, HIm. 16.
} 
bangsa Indonesia. Keadilan sosial pada dasarnya sulit dipahami apabila dia berdiri sendiri, oleh karenanya keadilan sosial harus menengok pada keadilan prosedural dan keadilan distributif dan keadilan komulatif. Menurut Notonagoro ${ }^{43}$ sebagaimana dikutip Kaelan, dalam kehidupan berbangsa dan bernegara keadilan sosial pada dasarnya dapat dirinci sebagai berikut :

a. Memelihara kepentingan umum yang khusus mengenai kepentingan bersama dari warga negara yang tidak dapat dilaksanakan oleh para warga negara sendiri;

b. Memelihara kepentingan bersama dari warga perseorangan yang tidak seluruhnya dapat dilaksanakan oleh para warga negara sendiri dalam bentuk bantuan dari negara;

c. Memelihara kepentingan dari warga perseorangan yang tidak seluruhnya dapat dilakukan oleh warga negara sendiri dalam bentuk bantuan dari negara. Ada kalanya negara memelihara seluruh kepentingan perseorangan (fakir miskin, anak terlantar);

d. Negara melindungi seluruh bangsa Indonesia, termasuk juga suku bangsa, keluarga, warga negara perseorangan;

e. Negara berkewajiban memajukan kesejahteran dan lingkungan ketinggian martabat kehidupan yang tinggi bagi setiap suku bangsa, setiap golongan warga negara, setiap keluarga, setiap warga negara perseorangan. Pelaksanaan pemeliharaannya dilakukan baik oleh negara maupun oleh perorangan sendiri tidak dengan bantuan negara atau dengan bantuan negara.

Berdasarkan berbagai pertimbangan dalam melihat keadilan sosial yang berkaitan dengan penyelesaian perselisihan penanaman modal asing di ICSID pada prinsipnya mencapai tujuan negara, Keadilan sosial dipandang sebagai keadilan yang memberikan kemanfaatan, keseimbangan dalam setiap pembentukan peraturan mengenai penyelesaian perselisihan penanaman modal asing. Oleh karena itu, bagi pandangan penulis keberadaan Indonesia sebagai anggota ICSID kurang tepat dan perlu dikaji kembali mengingat selama ini Indonesia lebih banyak kerugian yang ditimbulkan akibat menjadi negara anggota ICSID. Oleh karena itu perlu dibentuk regulasi khusus mengenai penyelesaian perselisihan penanaman modal asing yang berlandaskan pada nilai-nilai Pancasila yaitu Arbitrase ASEAN. Hal tersebut berangkat dari berlakuanya Masyarakat Ekonomi ASEAN (MEA) sejak akhir tahun 2015. Pembentukan arbitrase ASEAN diharapkan dapat menjadi win-win solution perselisihan penanaman modal, meskipun hingga saat ini organisasi yang menaungi 11 (sebelas) negara-negara di kawasan ASEAN tersebut belum membentuk lembaga arbitrase. Berikut perubahan penyelesaian perselisihan penanaman modal asing ICSID menjadi berbasis Pancasila.

\section{E. PENUTUP}

1. Simpulan

\footnotetext{
${ }^{43}$ Ibid, HIm. 222.
} 
a. Penyelesaian perselisihan penanaman modal yang melibatkan negara dengan warga negara asing di ICSID tidak adil dan tidak seimbang, serta mengalami kerugian besar ketika penyelesaian perselisihan antara negara dengan warga negara asing mengenai penanaman modal diserahkan kepada ICSID. Kerugian tersebut adalah biaya penyelesaian perselisihan penanaman modal asing sangat besar atau tidak efisien, tidak aksessiblity, tidak memproteksi para pihak dan sebagian putusan ICSID dapat dimintakan pembatalan.

b. Hukum nasional merupakan hukum yang dibangun oleh bangsa Indonesia berdasarkan nilai ketuhanan, nilai kemanusiaan dan nilai kemasyarakatan yang merupakan nilai agung dalam Pancasila sebagai pandangan hidup bangsa Indonesia guna mewujudkan tujuan negara. Oleh karena itu, perselisihan penanaman modal sebaiknya diselesaikan oleh badan arbitrase ASEAN.

2. Saran

Berdasarkan berbagai pertimbangan sebagaimana di atas maka penulis merekomendasikan agar pemerintah Republik Indonesia merevisi UndangUndang No. 5 Tahun 1968 tentang Penyelesaian Perselisihan Antara Negara Dengan Warga Negara Asing Mengenai Penanaman Modal sekaligus menyatakan sikap keluar dari keanggotaan ICSID.

\section{DAFTAR PUSTAKA :}

Buku :

Adolf, Huala dan An An Chandrawulan, Mekanisme Penyelesaian Sengketa Penanaman Modal, 2015, Bandung, Keni Media.

Fuady, Munir, Arbitrase Nasional : Alternatif Penyelesaian Sengketa Bisnis, 2000, Bandung, Citra Aditya Bakti

Mercuro, Nicholas dan Steven G Medumo, Economic and The Law : From Posner to Post-modernism, New Jersey, Princenton University Press.

Jawahir, Thantowi, Hukum Dan Hubungan Internasional, 2016, Jogjakarta, UII Press.

Mahfud MD, Muhammad, Membangun Politik Hukum Menegakkan Konstitusi, 2010, Jakarta, Rajawali Press

Mertokusumo, Sudikno, Mengenalkan Hukum Suatu Pengantar, 2003, Yoyakarta, Liberty

Nonet, Philippe dan Philip Selznick, Hukum Responsif, 2015, Bandung, Nusamedia 
Rahardjo, Satjipto, Negara Hukum yang Membahagiakan Rakyatnya, 2009, Yogyakarta, Genta Publishing. , Hukum Dalam Jagad Ketertiban, 2006, Jakarta, UKI Press ..Hukum Progresif Sebuah Sintesa Hukum Indonesia, 2009, Yogyakarta, Genta Publishing , Imu Hukum, 2000, Jakarta, Citra Aditya Bakti.

Samekto, Adji, Kapitalisme, Modernisasi, dan Kerusakan Lingkungan, 2008, Yogyakarta, Genta Press.

Sugianto, Fajar Economic Approach to Law, 2015, Jakarta, Kencanaprenada Media Group.

Suteki, Reformasi Politik Hukum Tentang Hak Menguasai Negara Atas Sumer Daya Air Berbasis Nilai Keadilan Sosial, Disertasi, Undip, Semarang

Wilardjo, Liek, Realita dan Desiderta, 1990, Yogyakarta, Duta Wacara University Press

\section{Jurnal}

Aldo Rico Deraldi, Analisis Keuntungan dan Kerugian Indonesia Terkait Opsi Penyelesaian Sengketa Investasi Indonesia Dengan Churchill Mining Plc di ICSID, 2015, Yogyakarta, Jurnal Penelitian Hukum, Volume 2, Nomor 2.

Delfiyanti, Perjanjian ASEAN Comprehensive Investment Aggremennt (ACIA) Tahun 2009 Prospek dan Tantangan Bagi Indonesia, 2014, Semarang, Jurnal Masalah-Masalah Hukum, Volume 43 No. 4, Hlm. 464-465

Nurnaningsih Amriani, Penerapan Prinsip Keterbukaan Atas Putusan Arbitrase ICSID di Indonesia dan Perbandingannya dengan Beberapa Negara, 2016, Medan, Jurnal Hukum dan Peradilan Volume 5 No. 1.

Sophie Dhinda Aulia Brahmana, Penyelesaian Sengketa Penanaman Modal Melalui Arbitrase Internasional (Studi Kasus Pencabutan Ijin Usaha Pertambangan Churchill Mining oleh Pemerintah Daerah Kabupaten Kutai Timur), 2013, Medan, Transparency Jurnal Hukum Ekonomi, FebMei. 
Widhayani Dian Pawestri, Dialektika perlindungan Kepentingan Nasional Berdasarkan Konstitusi Ekonomi Dengan Basic Prinsiple Dalam Bilateral Investment Treaties, 2016, Surabaya, Jurnal Yuridika, Volume 31 No. 1. 